\title{
Evaluation of a meal replacement-based weight management program in primary care settings according to the actual European Clinical Practice Guidelines for the Management of Obesity in Adults
}

\author{
Renate Kruschitz • Sandra Johanna Wallner-Liebmann · Harald Lothaller · Maria Luger • \\ Karin Schindler · Friedrich Hoppichler • Bernhard Ludvik
}

Received: 1 August 2013 / Accepted: 9 August 2014 / Published online: 6 September 2014

(C) The Author(s) 2014. This article is published with open access at Springerlink.com

\section{Summary}

Introduction The purpose of this study was the evaluation of a weight loss program in primary care settings with respect to the European Clinical Practice Guidelines for the Management of Obesity in Adults with regard to the long-term success of changes in body weight and composition.

Methods Overweight and obese patients $(n=1167)$ who underwent a standardized meal replacement-based weight loss program (myLINE ${ }^{\circledR}$, AENGUS, Austria) in primary care settings were included in this evaluation. Body composition was measured by conventional anthropometry and bioelectrical impedance analysis (AKERN BIA101 $^{\circledR}$, BIACORPUS RX4000 ${ }^{\circledR}$, SoftwareBodycomp Version 8.4 Professional). Data of patients who participated at least 12 months in the program were analyzed retrospectively and compared with their baseline data.

Results After 12 months, a weight loss of $8.6 \pm 7.5 \mathrm{~kg}$ (mean \pm standard deviation) or $8.2 \pm 7.8 \%$ from baseline was seen $(p<0.001)$. In all, $71.9 \%$ of all patients achieved

\footnotetext{
Assoc.-Prof. Dr. S. J. Wallner-Liebmann ( $\varangle) \cdot$ R. Kruschitz Institute of Pathophysiology and Immunology,

Medical University Graz,

Heinrichstraße 31a, 8010 Graz, Austria

e-mail: sandra.wallner@medunigraz.at

R. Kruschitz $\cdot$ M. Luger $\cdot$ K. Schindler $\cdot$ B. Ludvik

Department of Endocrinology and Metabolism,

Clinic for Internal Medicine III, Medical University Vienna,

Währinger Gürtel 18-20, 1090 Vienna, Austria

R. Kruschitz · M. Luger · F. Hoppichler

SIPCAN Special Institute for Preventive Cardiology and Nutrition, Guggenbichlerstraße 8/15, 5026 Salzburg, Austria

H. Lothaller

Fischergasse14/II/12, $8010 \mathrm{Graz}$, Austria

e-mail: statistik@lothaller.net
}

a minimal weight loss of $5 \%$, and $18.8 \%$ lost $15 \%$ of their initial weight. In comparison with the baseline $(35.7 \pm 11.5 \mathrm{~kg})$, body fat decreased to $29.6 \pm 10.7 \mathrm{~kg}$, which is $83.7 \pm 18.9 \%$ from baseline $(100 \%$; $p<0.001)$. Body cell mass showed an absolute reduction of $-1.4 \pm 2.2 \mathrm{~kg}$ $(p<0.001)$, although a relative increase of $1.5 \pm 2.5 \%$ $(p<0.001)$. There were no significant differences between male and female subjects regarding changes in weight, body fat, and body cell mass.

Conclusion The evaluated program complies with the European Clinical Practice Guidelines for Management of Obesity in Adults (2008), which recommend a weight reduction of 5-15\% from initial weight within 6 months. Furthermore, the data showed a significant reduction of body fat and a relative increase of body cell mass.

Keywords Weight loss program · Long-term effect · Primary care $\cdot$ Body composition · Obesity

Evaluierung eines im niedergelassenen Bereich durchgeführten ersatzmahlzeitenbasierten Adipositastherapieprogramms nach geltenden europäischen Richtlinien zur Behandlung von Adipositas bei Erwachsenen

\section{Zusammenfassung}

Ziel Evaluierung eines Adipositastherapieprogramms bezüglich der Konformität mit den European Clinical Practice Guidelines (2008) für das Management von Adipositas bei Erwachsenen und Kontrolle des Langzeiterfolgs anhand des Verlaufs von Körpergewicht und -zusammensetzung.

Methodik Übergewichtige Teilnehmer $\quad(n=1167)$ eines standardisierten, ersatzmahlzeitenbasierten Adipositastherapieprogramms (myLINE ${ }^{\circledR}$, AENGUS, Austria) wurden in österreichischen Arztpraxen ins Programm eingeschlossen. Die Körperzusammensetzung wurde 
mittels konventioneller Anthropometrie und Bioelektrischer Impedanz Analyse (AKERN BIA101 ${ }^{\circledR}$, BIACORPUS RX4000 ${ }^{\circledR}$, Software Bodycomp Version 8.4) erhoben. Die Daten jener Patienten, die zumindest 12 Monate im Programm waren, wurden retrospektiv analysiert und mit deren Ausgangsdaten verglichen.

Ergebnisse Nach 12 Monaten war ein Gewichtsverlust von $8,6 \pm 7,5 \mathrm{~kg}$ (mean $\pm \mathrm{SD}$ ) bzw. $8,2 \pm 7,8 \%$ $(p<0,001) \mathrm{zu}$ sehen. $71,9 \%$ aller Teilnehmer erzielten eine Gewichtsreduktion von mindestens 5 und 18,8\% eine Gewichtsreduktion von $15 \%$ ihres Ausgangsgewichts. Im Vergleich zum Körperfettanteil zu Programmstart $(35,7 \pm 11,5 \mathrm{~kg})$ betrug der Körperfettanteil nach 12 Monaten $29,6 \pm 10,7 \mathrm{~kg}$, das sind $83,7 \pm 18,9 \%$ vom Ausgangswert $(=100 \% ; p<0,001)$. Während der 12 Monate kam es zu einer Abnahme der absoluten Körperzellmasse von $-1,4 \pm 2,2 \mathrm{~kg}(p<0,001)$, gleichwohl nahm die relative Körperzellmasse um $1,5 \pm 2,5 \%(p<0,001)$ im Vergleich zum Programmstart zu. Es zeigten sich keine signifikanten Unterschiede zwischen den Geschlechtern hinsichtlich der Gewichts-, Körperfett- und Körperzellmasseentwicklung über den Beobachtungszeitraum.

Schlussfolgerung Das evaluierte Programm entspricht den European Clinical Practice Guidelines (2008) für die Therapie von Adipositas bei Erwachsenen, die eine Reduktion des Ausgangsgewichts von 5-15\% innerhalb von 6 Monaten empfehlen. Weiters zeigten sich eine signifikante Verringerung des Körperfettanteils und ein signifikanter Anstieg der relativen Körperzellmasse.

Schluisselwörter Gewichtsreduktionsprogram · Langzeiterfolg • Niedergelassener Bereich · Körperzusammensetzung · Adipositas

\section{Introduction}

The current Austrian Nutrition Report shows an approximately $40 \%$ prevalence of overweight and obesity among adults. Overweight is one of the most common health issues in Austria, as in many other European countries [1]. High body weight and fat are associated with an increased risk of cardiovascular complications, cer- tain cancers, diabetes mellitus, Alzheimer's disease, gallbladder disease, sleep apnea, osteoarthritis, renal disease, and musculoskeletal disorders [2-4]. A modest weight loss of $5-10 \%$ has been shown to reduce the risk of developing diabetes by $58 \%$ in at-risk patients [5] and reduces overall risk of mortality by $20 \%$ [6-8]. Effective weight reduction can decrease disease risk, lower the health service expenditure, and improve the quality of life in affected persons $[4,9,10]$. Studies have shown that structured treatment programs with regular followup improve long-term weight loss and maintenance [11, 12]. Obesity management programs at primary care level should underlie regular quality checks $[13,14]$. However, there is a lack of evidence about current approaches to obesity management in Austrian primary care.

In view of this fact, the present study evaluated the 12-month data based on the evaluation of changes in bodyweight and composition during the intervention and the follow-up phase of a standardized weight loss program conducted in primary care settings, according to the actual European Clinical Practice Guidelines for the Management of Obesity in Adults [15].

\section{Material and methods}

\section{Subjects}

A random sample of 1167 overweight participants (female $=979$, male $=188$; body mass index $(\mathrm{BMI}) \geq 25 \mathrm{~kg}$ / $\mathrm{m}^{2}$ ) has been included in the weight loss program in 250 Austrian primary care settings.

Data of men and women who attended the program at least 12 months without interruption have been analyzed, and their results were compared with their baseline data. Exclusion criteria were BMI $<25 \mathrm{~kg} / \mathrm{m}^{2}$, diabetes mellitus, being pregnant or lactating, cardiovascular disease, other medical conditions prohibiting weight loss, substance abuse, severe psychiatric illness, and eating disorders (anorexia nervosa, bulimia nervosa, binge eating disorder). The corresponding descriptive statistic is presented in Table 1.

Table 1 Descriptive characteristic at baseline

\begin{tabular}{|c|c|c|c|c|}
\hline & Men & Women & Significance of differences ${ }^{a}$ & Total \\
\hline Number & 188 & 979 & & 1167 \\
\hline Age (years) & $49.2 \pm 13.8$ & $46.5 \pm 13.3$ & n.s. ${ }^{b}$ & $46.9 \pm 13.4$ \\
\hline Weight (kg) & $107.5 \pm 16.3$ & $89.5 \pm 17.7$ & $p<0.001$ & $92.3 \pm 18.7$ \\
\hline BMI $\left(\mathrm{kg} / \mathrm{m}^{2}\right)$ & $34.1 \pm 5.0$ & $33.0 \pm 6.3$ & $p=0.004$ & $33.1 \pm 6.1$ \\
\hline Fat mass $(\mathrm{kg})$ & $32.4 \pm 9.9$ & $35.9 \pm 11.7$ & $p<0.001$ & $35.7 \pm 11.5$ \\
\hline BCM (kg) & $39.1 \pm 5.9$ & $26.3 \pm 3.9$ & $p<0.001$ & $28.5 \pm 6.5$ \\
\hline \multicolumn{5}{|c|}{$\begin{array}{l}\text { Data are mean } \pm \text { standard deviation } \\
\text { BMI body mass index, } B C M \text { body cell mass } \\
\text { aDifferences in the distributions of variables between men and women were tested by Student's } t \text {-test for two independent samples (in case of normally distrib- } \\
\text { uted variables) and by Mann-Whitney } U \text {-test for two independent samples (if variables were not normally distributed) } \\
\text { bNot significant ( } p>0.05 \text { ) }\end{array}$} \\
\hline
\end{tabular}


The procedures used in this evaluation were in accordance with the Declaration of Helsinki (1964) and its later amendments. The study is approved and registered under No 2107/2013 of the ethics committee of the Medical University of Vienna. All participants gave their written informed consent prior to their inclusion into the program.

\section{Program design}

The myLINE ${ }^{\circledR}$-program (www.myline.at, AENGUS, Austria) is a standardized, meal replacement-based weight loss program for at least 24 weeks. The diet is in accordance with the latest nutritional recommendations of the German Nutrition Society (DGE), the Austrian Nutrition Society (ÖGE), the Swiss Nutrition Society (SGE), and the Swiss Association for Nutrition (SVE), which are called DACH-recommendations.

The program consists of four phases:

1. Starting phase: During the first 2 days, the participants use exclusively a very low-calorie diet. Five meal replacements should be eaten on a regular basis every $3 \mathrm{~h}$.

Total energy intake: $835 \mathrm{kcal} / \mathrm{day}, 60.0 \mathrm{~g} /$ day of protein, $15.5 \mathrm{~g} /$ day of fat, and $100.0 \mathrm{~g} /$ day of carbohydrates.

2. Reduction phase: Beginning with the third day, two out of three meals should be replaced by an energy-reduced standard diet for weight control, and one meal should be eaten as regular fat-reduced food.

Participants are trained in creating their meal according to an exchange schema. The total fat content is $\leq 30 \%$ of the daily energy intake. The reduction phase should be undertaken until the participant achieves two-thirds of the intended weight reduction, but at least for 10 weeks.

Total energy intake: 1000-1300 kcal/day, 50-65 g/day of protein ( 20 energy percent (E\%)), 34-44 g/day of fat ( $30 \mathrm{E} \%)$, and 125-160 g/d of carbohydrates ( 50 E\%). For persons with a high body cell mass (BCM), the content of proteins would be individually adjusted.

3. Transitional phase: The beginning of the transitional phase is determined individually, but the participant should have performed the phase 3 for at least 10 weeks. In this phase, at least one meal should be replaced and the other two should be eaten as a fat-reduced mixed meal.

Total energy intake: 1300-1600 kcal/day, 50-65 g/day of protein ( $20 \mathrm{E} \%), 34-44 \mathrm{~g} /$ day of fat $(\sim 30 \mathrm{E} \%)$, and 160-200 g/day of carbohydrates ( $50 \mathrm{E} \%)$. For persons with a high BCM, the content of proteins would be individually adjusted.

4. Stabilization phase: Due to the acquired knowledge on how to arrange their meals correctly and how to adjust their energy intake to their daily requirements, the participants should maintain their weight without meal replacements. In this phase, they should eat three meals per day regularly.
During the whole program, at regular intervals (start, reduction, and transition phase: every 14 days; stabilization phase: once a month; afterward four times a year), the participants were measured by bioelectrical impedance analysis (BIA) and conventional anthropometry and received individual nutritional advice from a registered dietician. In the context of individual face-to-face consultations, aims and treatment plans, also including improvement of the activity level in accordance with the actual recommendations, are defined. A nutrition and activity diary for self-reflection and a participant handbook for support and exercises at home are used as instruments of behavior therapy.

After the weight reduction, there is the possibility to participate in a follow-up program. Regular controls should improve long-term weight loss and weight maintenance.

\section{Meal replacement}

The declaration of all products took place at the Austrian Federal Ministry of Health as foods intended for use in energy-restricted diets for weight reduction. All products are in accordance with the directive 96/8/EG of the European dietetic food regulation. Furthermore, products undergo regular laboratory controls and are only available in primary care units in combination with regular follow-up examinations [16].

\section{Measure of body composition}

The measurement of body composition was performed by conventional anthropometry (weight, height, waist circumference) and BIA (AKERN BIA 101 ${ }^{\circledR}$, BIACORPUS $\mathrm{RX} 4000^{\circledR}$, Software Bodycomp version 8.4 professional).

\section{Statistics}

Statistical analysis was performed by SPSS for Windows Version 17.0 (SPSS Inc., Chicago). All results are presented as mean \pm standard deviation (SD). Differences in the distributions of variables between men and women were tested by Student's $t$-test for two independent samples (in case of normally distributed variables) and by Mann-Whitney $U$-test for two independent samples (if variables were not normally distributed). Comparison between baseline and 12 months was done using analysis of variance. $p$-Values $<0.05$ were considered as significant.

\section{Results}

All participants who underwent the program for at least 12 months without interruption were included in the evaluation. Their baseline characteristics are presented 
in Table 1. Men showed a higher weight $(p<0.001)$, BMI $(p<0.001)$ and muscle mass $(p<0.001)$ and lower fat mass $(p<0.001)$ in comparison with women at baseline, although there were no significant differences between male and female in the development of weight, body fat, and BCM during the observation period.

After 12 months, a weight loss of $8.6 \pm 7.5 \mathrm{~kg}$ (mean \pm SD) or $8.2 \pm 7.8 \%$ was seen $(p<0.001$; Table 2$)$, which corresponds to a loss of excess weight of $28 \%$. In all, $71.9 \%$ of all participants reached a minimal weight loss of $5 \%$, $40 \%$ lost $10 \%$, and $18.8 \%$ of the participants lost $15 \%$ of their initial weight. These findings correspond to a mean BMI reduction of $3.1 \pm 2.7$ units $(p<0.001$; Table 2$)$. A total of $81.5 \%$ of the participants achieved a minimum BMI reduction of 1 unit after 12 months. Body fat decreased by $6.2 \pm 5.9 \mathrm{~kg}(p<0.001$; Table 2$)$. In comparison with baseline data of $35.7 \pm 11.5 \mathrm{~kg}$, body fat decreased to $29.6 \pm 10.7 \mathrm{~kg}$ after 12 months, which is $83.7 \pm 18.9 \%$ from baseline $(100 \% ; p<0.001$; Table 2). With regard to the time course of weight loss, we could obtain data from a smaller sample (70 from 1167 patients), which showed that the maximum body weight and body fat reduction was achieved after 6 months. Furthermore, BCM showed an absolute decrease of $-1.4 \pm 2.2 \mathrm{~kg}(p<0.001)$, but a relative increase of $1.5 \pm 2.5 \%(p<0.001)$ after 12 months (Table 2).

\section{Discussion}

Successful weight reduction and weight maintenance after weight reduction is the greatest challenge in the therapy of obesity. Effective methods to achieve this ambitious goal, especially in primary care, are required $[17,18]$. In this study, a meal replacement-based weight management program was evaluated according to the actual European Clinical Practice Guidelines for the Management of Obesity in Adults, with respect to the longterm success regarding changes in body weight and body composition. As defined by the European Guidelines, a weight reduction of 5-15\% within 6 months or $0.5-1.0 \mathrm{~kg}$ per week is realistic and desirable [15]. International committees consider a weight reduction of $5-10 \%$ of the initial body weight as adequate to reduce the health risk in obese patients $[15,19]$. Additionally, Hauner et al. [13] defined success for obesity therapy programs in primary care as follows: at least $50 \%$ of the participants have to lose $5 \%$ of their initial weight, and $20 \%$ should achieve a weight reduction of $10 \%$ from baseline. For the definition of long-term success, there exists no uniform definition. The Institute of Medicine defines long-term success as an achieved body weight at least $5 \%$ below the initial weight or a BMI at least one unit below the baseline BMI 1 year after weight reduction [20]. Wing and Hill [21] proposed that successful weight loss maintainers are defined as patients who initially have lost at least $10 \%$ of their body weight and stabilized at least for 1 year. The Clinical Guidelines on Evaluation and Treatment of Overweight and Obesity in Adults have defined successful weight maintenance after weight loss as a weight regain of less than $3 \mathrm{~kg}$ in 2 years [22].

In the case of the evaluated program, the average weight reduction was $8.6 \mathrm{~kg}$ or $8.2 \%$ after 12 months. Compared with the data of Franz et al. [23], which systematically reviewed the long-term effect of 80 different medical weight loss interventions, the present data are well within or even above the reported range. In the current study, approximately three-quarter of the participants reached a weight reduction of $5 \%$, and $40 \%$, a reduction of $10 \%$. Due to the program structure, it is subsequently not possible to provide an accurate retention rate, as participants may achieve their weight goal before 12 months or some may stop the program after a shorter period than 12 months and restart it again afterward, which can therefore not be defined as dropouts.

BMI after 12 months was, on average, 3 units lower compared with the BMI at the beginning of the program. These results are in accordance with the criteria referred earlier in the text. Long-term weight loss was greater than weight loss observed in other primary care trials [24-27], with the exception of a study involving morbidly obese patients who were treated with intensive group lifestyle modification and weight loss medications [28].

Reduction in body fat and preservation of lean body mass are crucial for beneficial metabolic effects and prevention of weight regain and sarcopenic obesity due to

Table 2 Body composition data from baseline to 12 months

\begin{tabular}{|c|c|c|c|c|}
\hline$N=1167$ & Baseline & 12 months & $\begin{array}{l}\text { Differences between BL and } \\
12 \text { months }\end{array}$ & Significance of differences ${ }^{a}$ \\
\hline Weight (kg) & $92.3 \pm 18.7$ & $83.7 \pm 16.8$ & $-8.6 \pm 7.5$ & $p<0.001$ \\
\hline BMI $\left(\mathrm{kg} / \mathrm{m}^{2}\right)$ & $33.1 \pm 6.1$ & $30.0 \pm 5.5$ & $-3.1 \pm 2.7$ & $p<0.001$ \\
\hline Fat Mass (kg) & $35.7 \pm 11.5$ & $29.6 \pm 10.7$ & $-6.2 \pm 5.9$ & $p<0.001$ \\
\hline Fat Mass (\%) & $38.2 \pm 6.9$ & $34.7 \pm 7.3$ & $-3.5 \pm 3.9$ & $p<0.001$ \\
\hline BCM (kg) & $28.5 \pm 6.5$ & $27.1 \pm 6.1$ & $-1.4 \pm 2.2$ & $p<0.001$ \\
\hline BCM (\%) & $31.2 \pm 4.8$ & $32.7 \pm 5.0$ & $1.5 \pm 2.5$ & $p<0.001$ \\
\hline
\end{tabular}


loss of BCM [18]. White adipose tissue is recognized as an active endocrine tissue that secretes numerous immunomodulatory factors that play major roles in regulation of human metabolic and vascular biology, and is therefore significantly involved in the pathogenesis of the metabolic syndrome [29]. The collected data showed a body fat reduction of $16 \%$ from baseline to 12 months, which suggests a metabolically effective weight reduction, which we cannot prove due to the lack of respective labor parameters. During the observation period, we could observe an increase of relative BCM despite a decrease of absolute BCM indicating a satisfactory overall development of muscle mass despite weight reduction.

A possible explanation for the success of the examined weight management program may be the intensive patient contact, the individual dietary counseling, and the guidance for physical activity, as well as the standardized optimal nutrient intake. One essential component of the program is a long-term modification of dietary and physical activity habits. The program supports the participants during and after the weight reduction with behavior-therapeutical modules as a nutritional and physical activity diary, for patient self-monitoring and as a basis for the therapeutic one-on-one counseling, through a participant handbook and group meetings, as a communication platform for participants, and for increasing their nutritional knowledge. In further studies, the quality of participant contact and participant satisfaction in this program was evaluated [16, 30-32], and therefore, the program complies with the requirements of regular quality checks of obesity programs in primary care [13].

\section{Conclusion}

The evaluated program complies with national and international guidelines for the therapy of obesity in adults and is efficient with regard to long-term therapeutic use in primary care. The results emphasize the importance of regular body composition measurements during weight reduction. The findings reveal a significant reduction of body weight, body fat, and a relative increase of BCM after 12 months. Participants underwent regular controls with conventional anthropometry, BIA measurements, and dietary advice from a registered dietician, and, in addition, behavior-therapeutical tools supported them during and after weight reduction. The program represents an intensified conventional obesity therapy with ongoing quality checks. Further studies with an observation period of more than 12 months in consideration of metabolic parameters are needed to examine the longterm weight development and the metabolic effect of this weight management program.

\section{Conflict of interest}

Sandra Johanna Wallner-Liebmann and Bernhard Ludvik provide gratuitous service for the companies' scientific advisory board. Renate Kruschitz, Maria Luger,
Karin Schindler, and Friedrich Hoppichler declare that they have no conflict of interest.

\section{Open Access}

This article is distributed under the terms of the Creative Commons Attribution License which permits any use, distribution, and reproduction in any medium, provided the original author(s) and the source are credited.

\section{References}

1. Elmadfa I, Freisling H, Nowak V, Hofstädter D. Österreichischer Ernährungsbericht 2012.1. Auflage, Wien; 2012.

2. Meyer H, Sogaard A, Tverdal A, Selmer R. Body mass index and mortality: the influence of physical activity and smoking. Med Sci Sports Exerc. 2002;34(7):1065-70.

3. Must A, Spadano J, Coakley EH, Field AE, Colditz G, Dietz $\mathrm{WH}$. The disease burden associated with overweight and obesity. JAMA. 1999;282:1523-9.

4. Bachmann K. Obesity, weight management, and health care costs: a primer. Dis Manag. 2007;10(3):129-37.

5. Tuomilehto J, Lindstrom J, Eriksson J, et al. Prevention of type 2 diabetes mellitus by changes in lifestyle among subjects with impaired glucose tolerance. N Engl J Med. 2001;344:1343-9.

6. Williamson D, Thompson T, Thun M, Flanders D, Pamuk $\mathrm{E}$, Byers T. Intentional weight loss and mortality among overweight individuals with diabetes. Diabetes Care. 2000;23:1499-504.

7. Williamson D, Pamuk E, Thun M, Flanders D, Byers T, Heath C. Modest intentional weight loss increases life expectancy in overweight women. Am J Epidemiol. 1995;141:1128-41.

8. Lean M, Powrie J, Anderson A, Garthwaite P. Obesity, weight loss and prognosis in type 2 diabetes. Diabet Med. 1990;7:228-33.

9. Laws R, Reckless J, on behalf of the Counterweight Project Team. Differences in disease prevalence between obese and normal weight individuals. Int J Obes. 2003;7(1):83.

10. de Zwaan M, Petersen I, Kaerber M, et al. Obesity and quality of life: a controlled study of normal-weight and obese individuals. Psychosomatics. 2009;50(5):474-82.

11. Perri M, Sears S, Clark J. Strategies for improving maintenance of weight loss: toward a continuous model of care. Diabetes Care. 1993;16:100-9.

12. Lantz H, Peltonen M, Aren L, Torgerson J. A 4-year clinical trial and a long-term posttreatment follow-up. J Int Med. 2003;254:272.

13. Hauner H, Wechsler J, Kluthe R, et al. Qualitätskriterien für ambulante Adipositasprogramme. Aktuelle Ernaehr Med. 2000;25:163-5.

14. Hauner H, Buchholz G, Hamann A, et al. Evidenzbasierte Leitlinie: Prävention und Therapie der Adipositas. DAG, DDG, DGE, DGEM; 2007. Retrieved 03.03.2008, from http://www.adipositas-gesellschaft.de/daten/AdipositasLeitlinie-2007.pdf

15. Tsigos C, Hainer V, Basdevant A, et al. Management of obesity in adults: European clinical practice guidelines. Obes Facts. 2008;1:106-16.

16. Wallner S, Wascher T. Qualitätsanalyse von Adipositasprogrammen am Beispiel von myLINE-Ernährung und Bewegung, einer Adipositas-Therapie beim niedergelassenen Arzt. J Ernährungsmed. 2006;8(3):11-6.

17. Kassirer J, Angell M. Losing weight-an ill-fated new year's resolution. N Engl J Med. 1998;338:52-4. 
18. Santarpia L, Contaldo F, Pasanisi F. Body composition changes after weight-loss interventions for overweight and obesity. Clin Nutr. 2013;32(2):157-61.

19. National Heart Lung and Blood Institue. Clinical guidelines on the identification, evaluation, and treatment of overweight and obesity in adults: the evidence report. Obes Res. 1998;6:51-210.

20. Thomas P, editors. Weighing the options: criteria for evaluating weight-management programs. Washington: National Academic Press; 1995.

21. Wing R, Hill J. Successful weight loss maintenance. Annu Rev Nutr. 2001;21:323-41.

22. Stevens J, Truesdale K, McClain J, Cai J. The definition of weight maintenance. Int J Obes. 2006;30:391-9.

23. Franz M, Van Wormer J, Crain A, et al. Weight-loss outcomes: a systematic review and meta-analysis of weightloss in clinical trials with a minimum 1 year follow-up. J Am Diet Assoc. 2007;107:1755-67.

24. Martin P, Dutton G, Rhode P, Horswell R, Ryan D, Brantly P. Weight loss maintenance following a primary care intervention for low-income minority women. Obesity. 2008;16(11):2462-7.

25. Kumanyika S, Fassbender J, Sarwer D, et al. One-year results of the Think Health! study of weight management in primary care practices. Obesity. 2012;20(6):1249-57.

26. Cohen M, D'Amico F, Merenstein J. Weight reduction in obese hypertensive patients. Fam Med. 1991;23:25-8.
27. Christian J, Bessesen D, Byers T, Christian K, Goldstein M, Bock B. Clinic-based support to help overweight patients with type 2 diabetes increase physical activity and lose weight. Arch Intern Med. 2008;168:141-6.

28. Ryan D, Johnson W, Myers V, et al. Nonsurgical weight loss for extreme obesity in primary care settings: results of the Louisiana Obese Subjects Study. Arch Intern Med. 2010;170:146-54.

29. Hutley L, Prins J. Fat as an endocrine organ: relationship to the metabolic syndrome. Am J Med Sci. 2005;330(6):280-9.

30. Wallner S, Piccoli A, Lothaller H, Liebmann P, Schnedl W, Schaunstein K. Body composition changes during a program for fat loss in obesity. Evaluation with conventional and vector bioelectrical analysis. In: Abstracts of the 10th International Congress on Obesity (IOC); 2006 Sept 3-8; Sydney. Vol. 7, No. 2, p. 178.

31. Kruschitz R, Lothaller H, Wascher T, Liebmann P, Schnedl W, Wallner S. Evaluation of weight-management programs and the impact of the return ration of questioning. Aktuelle Ernärungsmed. 2007;3:137-46.

32. Kruschitz R, Lothaller H, Liebmann P, Schnedl W, Wallner S. Successful weight maintenance and body composition: a 6-30 months follow-up. In: Abstract of the European Congress on Obesity (ECO); 2008 May 14-17; Geneva, Switzerland. 